\title{
FROM THE SPIRIT OF THE FEDERALIST PAPERS TO THE END OF LEGITIMACY: REFLECTIONS ON GUNDY V. UNITED STATES
}

\author{
By J. Benton Heath
}

\begin{abstract}
The revival of the nondelegation doctrine, foreshadowed last term in Gundy v. United States, signals the end of a distinctive style of legal and political thought. The doctrine's apparent demise after the 1930s facilitated the development of a methodological approach that embodied what Lon Fuller once called "the spirit of the Federalist Papers": an openended engagement with the problem of designing democracy and controlling public power. At its best, this discourse was critical and propulsive, with each purported solution generating more questions than it answered. The turn against congressional delegations will likely bring to a close this period of open and self-critical experimentation. In its place, we are likely to see the emergence of warring visions of the administrative state, each claiming legitimacy-neither credibly-according to its own comprehensive normative doctrine.
\end{abstract}

AUTHOR-Acting Assistant Professor of Lawyering, New York University School of Law. Many thanks to Edith Beerdsen, Dominic Budetti, Harlan Cohen, Michael Pollack, David Simson, Richard B. Stewart, Thomas Streinz, and David Zaring for helpful comments and discussions, and thanks to Danielle Berkowsky and the staff of the Northwestern University Law Review for careful and conscientious editing. 


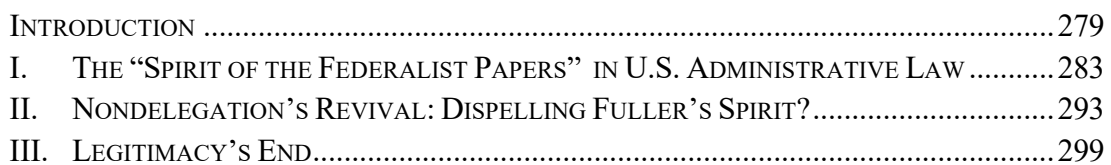

\section{INTRODUCTION}

In 1963, the United States' leading professor of jurisprudence issued a provocative call to rethink administrative law. ${ }^{1}$ Legality, Lon Fuller observed, depended on certain fundamental attributes - an "internal morality"- that demanded a minimal degree of clarity, generality, prospectivity, and consistency in application, and a system that wholly lacked one of these attributes would not be a "legal system" in any meaningful sense of the term. ${ }^{2}$ It was not lost on Fuller that law's internal morality presented a fundamental challenge for the administrative state, which was then about to enter a period of remarkable growth. A legal system of clear, stable, and generally applicable rules laid down in advance was well-suited to facilitating free-market capitalism, but these same principles stood in fundamental tension with alternative, more interventionist forms of social and economic organization. ${ }^{3}$ To the extent that modern government was called upon to intervene in markets, regulate industry, and set contentious social policy, Fuller's internal morality of law would seem an obstacle rather than an ideal. ${ }^{4}$ It seemed, in other words, that we were faced with a zero-sum choice: either uphold the rule of law or embrace the administrative state.

This dilemma, Fuller insisted, required a careful and critical response. The emerging institutions of the administrative state would entail tradeoffs

\footnotetext{
1 See generally LON L. Fuller, THE MORALiTy OF LAW (rev. ed. 1969). This, of course, is not how Lon Fuller's 1963 Storrs Lectures, later published as the Morality of Law, are ordinarily remembered today; lawyers and legal theorists are far more likely to have encountered Fuller in the context of the ongoing debate between positivism and natural law. See, e.g., Benjamin C. Zipursky, The Inner Morality of Private Law, 58 AM. J. JURIS. 27, 27-31 (2013). Others have noted the potential incompatibility of Fuller's theory of law to the administrative state, though they understate the extent to which Fuller himself grappled with these issues. See, e.g., Edward L. Rubin, Law and Legislation in the Administrative State, 89 Colum. L. REV. 369, 397-408 (1989); Peter L. Strauss, Legislative Theory and the Rule of Law: Some Comments on Rubin, 89 Colum. L. Rev. 427, 444 (1989); Cass R. Sunstein \& Adrian Vermeule, The Morality of Administrative Law, 131 HARV. L. REV. 1924, 1927 (2018).

2 FULLER, supra note 1, at 33-94, 96.

3 See id. at 24-25 (citing FrIedrich A. HAYEK, THE ROAD TO SERfDOM (1944)); E. B. Pashukanis, The General Theory of Law and Marxism, in SOVIET Legal PHILOSOPHY 111, 111-225 (Hugh W. Babb trans., 1951). See generally Lon L. Fuller, Pashukanis and Vyshinsky: A Study in the Development of Marxist Legal Theory, 47 MicH. L. REV. 1157 (1949).

${ }^{4}$ See, e.g., FULLER, supra note 1, at 170-81.
} 
between the internal morality of law and other pressing social values and policies-tradeoffs that can have profound ramifications for individuals' lives and for the use of public power. ${ }^{5}$ It would be a mistake to assume that the new institutions of the administrative state must be governed according to the same principles of legality that applied to the institutions of laissezfaire capitalism, just as it would be a mistake to indiscriminately deploy governmental power for one's chosen ends without any concern for institutional checks. ${ }^{6}$ In other words, the growth of administrative power demanded not a zero-sum choice, but subtle and ongoing attention to the problems of institutional design: "Something like the spirit of the Federalist Papers will become essential — a spirit at once inquiring and constructive."

This Essay reconstructs what Fuller meant by the "spirit of the Federalist Papers" and argues that something like this spirit actually did come to characterize the theory and practice of U.S. administrative law in the ensuing decades. Fuller's "spirit," at least as this Essay reconstructs it, denotes a continuing and open-ended engagement with the problems of designing institutions to control and channel political power. It is concerned with the values that are embedded and reflected in everyday institutional arrangements, and it seeks to bring those values to light and subject them to scrutiny. ${ }^{8}$ This spirit is "inquiring and constructive," in the sense that its practitioners are constantly seeking new ways to design regulatory policies, programs, and bureaucracies. The process of investigation, critique, and revision is ongoing as successive generations continually attempt to find "the most apt institutional design for governmental control" 10 over a changing economy. The "spirit of the Federalist Papers," then, is exemplary of what Jeremy Waldron calls "political political theory - theory addressing itself to politics and to the way our political institutions house and frame our disagreements about social ideals and orchestrate what is done about whatever aims we can settle on."11

\footnotetext{
5 See id. at 179. Fuller's argument thus presages the "institutional choice" approach outlined in NEIL

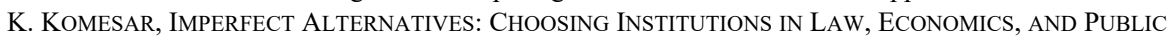
POLICY (1994).

${ }^{6}$ FULLER, supra note 1, at 181.

${ }^{7}$ Id.

${ }^{8}$ For an approach that bears a family resemblance to Fuller's spirit, but in a different substantive and philosophical tradition, see Joshua Kleinfeld, A Theory of Criminal Victimization, 65 STAN. L. REV. 1087, 1151 (2013).

9 See FULLER, supra note 1, at 181.

${ }^{10} \mathrm{Id}$. at 175. In a passage notable for its relevance to the present day, Fuller stresses that the administrative apparatus has already struggled to grapple with transformations in the economy and warns that it will in the future have to deal with "the as yet largely unfaced dislocations that will be brought by increasing automation." Id. at 176.

11 Jeremy Waldron, Political Political Theory: Essays on Institutions 6 (2016).
} 
In the U.S. administrative state, Fuller's own call for a renewed spirit of engagement may have been largely ignored, ${ }^{12}$ but his words nonetheless proved prophetic. Over the next decade, a discourse emerged that interrogated the normative foundations of the administrative state, asking whether and on what terms it could be legitimated by reference to democratic principles. ${ }^{13}$ At its best, this discourse was critical and propulsive, with each purported solution generating more questions than it answered. ${ }^{14}$ The administrative state became a distinctive and productive laboratory for rethinking the role of democratic governance under conditions of extreme complexity: "massive" and "wicked" problems, ${ }^{15}$ the demand for extensive technical knowledge, ${ }^{16}$ and globalization. ${ }^{17}$ But this thinking took place- - had to take place-against a background assumption, with which Fuller concurred, that the kind of administrative state we need will never be effectively controlled and legitimated through general and prospective rules laid down in advance by a watchful legislator.

This background assumption, of course, was never shared by a large and influential proportion of U.S. politicians and legal professionals who remained skeptical of the administrative state. On June 20, 2019, this skeptical position secured a preliminary but significant victory in Gundy $v$. United States, wherein four Justices signaled their desire to reconsider the Court's longstanding, hands-off approach to broad delegations by Congress to administrative agencies. ${ }^{18}$ On this view, the proper guide for designing, coordinating, and legitimating the administrative state is not the "spirit" of the Federalist Papers, but the Federalist Papers themselves, along with other indicia of the Constitution's original meaning and purpose. ${ }^{19}$ And the Constitution, on the skeptical view, forbids overly broad delegations from

\footnotetext{
12 I have found no other piece engaging specifically with this part of Fuller's best-known work. In preparing this piece, I was surprised to find I may be the only law review author to have expressly referenced this "spirit of the Federalist Papers," despite more than 1,800 citing references to Fuller's book in leading legal databases. See J. Benton Heath, Global Emergency Power in the Age of Ebola, 57 HARV. INT'L L.J. 1, 47 (2016).

13 See infra Part I.

14 See, e.g., infra notes 50-52 and accompanying text (describing the emergence of a model of "interest representation" in administrative law and the problems attending that model).

15 E.g., J.B. Ruhl \& James Salzman, Climate Change, Dead Zones, and Massive Problems in the Administrative State: A Guide for Whittling Away, 98 CALIF. L. REV. 59, 72-79 (2010).

16 E.g., Martin Shapiro, "Deliberative," "Independent" Technocracy v. Democratic Politics: Will the Globe Echo the E.U.?, 68 L. \& CONTEMP. PROBS. 341, 342-44 (2005).

17 See generally ANNE-MARIE SLAughter, A NEW WORLD ORDER (2004) (describing the emergence of global regulatory networks).

18139 S. Ct. 2116, 2118-20 (2019) (Alito, J., concurring in the judgment); id. at 2131 (Gorsuch, J., dissenting).

19 See id. at 2133-35 (Gorsuch, J., dissenting).
} 
Congress to the Executive, and empowers the federal courts to police and invalidate those delegations in the service of individual liberty and deliberative democracy. ${ }^{20}$

The upshot of this approach is that the broad delegations on which much of the administrative state is founded may now be "under siege," ${ }^{21}$ awaiting only a clever litigant and a fifth vote from Justice Kavanaugh, who took no part in Gundy. Commentators have already observed that the resurrection of the nondelegation doctrine would jeopardize large segments of the administrative state and make future ambitious policymaking all the more difficult by forcing Congress to reach far broader agreement before passing legislation. ${ }^{22}$ Four Supreme Court Justices appear to agree, warning that if the measure in Gundy is impermissible, as the dissent argues, then "most of Government is unconstitutional." ${ }^{23}$ In the wake of the Gundy dissent, commentators have argued that the administrative state is too much a practical necessity, that the nondelegation doctrine is too blunt a tool, and that its resurrection is neither required by the Constitution nor normatively desirable. ${ }^{24}$

The argument I advance here is at a different level of reflection. I contend that this turn against congressional delegations signifies a profound transformation in our political and intellectual life. It brings to a close whatever was left of the broadly experimentalist approach to institutional design that was presaged in Fuller's lectures. In the place of an ongoing, selfcritical search for legitimacy, we are likely to find hardened battle lines, with each side offering a romanticized ideal model of governance. This is not only

\footnotetext{
20 See id. at 2134-35.

${ }^{21}$ See generally Gillian E. Metzger, Foreword: 1930s Redux: The Administrative State Under Siege, 131 HARV. L. REV. 1 (2017) (charting the rise of "anti-administrativism" on the U.S. Supreme Court).

${ }^{22}$ See, e.g., Todd Tucker, How a Sex Offender's Case Before the Supreme Court Could Bring Down the Administrative State, POLITICO (June 2, 2019), https://www.politico.com/magazine/story/2019/ 06/02/supreme-court-gundy-rapist-227038 [https://perma.cc/9AMT-LDCV]; Nicholas Bagley, Opinion, 'Most of Government Is Unconstitutional,' N.Y. TIMES (June 21, 2019), https://www.nytimes.com/ 2019/06/21/opinion/sunday/gundy-united-states.html [https://perma.cc/6DZX-DLHZ].

23 Gundy, 139 S. Ct. at 2130 (plurality opinion).

24 See, e.g., Bagley, supra note 22 ("To run a functional, modern government, Congress has no choice but to delegate authority and discretion to federal agencies. Doing so allows Congress to make use of agencies' resources and scientific expertise, to enable a nimble response to emerging problems and to insulate technocratic decisions from raw politics."); Scott Lemieux, Wait a Minute, Could John Roberts Block All of This?, AM. PROSPECT (Sept. 27, 2019), https://prospect.org/day-one-agenda/chief-justiceroberts-block-executive-authority [https://perma.cc/45YF-FBDR] (warning that the revival of the nondelegation doctrine could frustrate initiatives by a progressive governing coalition); Julian Davis Mortenson \& Nicholas Bagley, Delegation at the Founding (Dec. 31, 2019) (unpublished manuscript), https://papers.ssrn.com/a=3512154 [https://perma.cc/H8DP-W6B9] (arguing that the nondelegation doctrine, as understood by contemporary conservative judges and scholars, was not part of the original constitutional understanding).
} 
a reflection of our oft-bemoaned political polarization. It also represents the loss of a distinctive style of legal and political inquiry, which continually sought to reconsider and reconcile the demands of democratic constitutionalism with the exigencies of contemporary life.

This is not, in other words, an additional argument for keeping the nondelegation doctrine in mothballs. The observations presented here are unlikely to move the needle for anyone who is ideologically opposed to the modern expansion of the administrative state or who believes that "most of the modern national government is wildly, absurdly, it-is-not-even-a-closecall-obviously unconstitutional." ${ }^{25}$ The purpose of this reflection is, instead, to mark a transformative shift in our constitutional and administrative politics. What is at stake in this shift, I argue, is the important role of U.S. administrative agencies in testing what democracy can and should look like in an increasingly complex, technocratic, and globalized world. And, unlike the fight over the nondelegation doctrine itself, which still must play out in the courts, this shift may have already taken place.

This Essay proceeds in three Parts. Part I argues that the decade following Fuller's lecture did indeed lead to a spirit of constructive, crucial, and principled engagement with the administrative state, which left a heavy mark on administrative law scholarship and practice both in the United States and abroad. Part II then turns to the dissenting opinion in Gundy, which heralds a return of the nondelegation doctrine, and shows how the approach announced in this opinion signals a radical shift in the political discourse. Part III concludes by considering the implications of this shift for our ability to critically engage and experiment with alternatives in institutional design.

\section{THE "SPIRIT OF THE FEDERALIST PAPERS" IN U.S. ADMINISTRATIVE LAW}

The complex of agencies, bureaucrats, regulations, and practices that make up the administrative state is in some ways the most salient feature of modern government. ${ }^{26}$ Whether one is running a business, receiving public assistance, muddling through airport security, or, like Herman Gundy, negotiating the immense and often lifelong consequences of being convicted of a crime, ${ }^{27}$ administrative law is a part of one's life, even more so than the

\footnotetext{
25 Gary Lawson, Right About the Constitution, BALKInIZATION (June 5, 2019), https://balkin.blogspot.com/2019/06/right-about-constitution.html [https://perma.cc/Y9X4-9JZB].

26 "Modern government," as one leading casebook puts it, "is administrative government." STEPHEN G. Breyer et al., Administrative LaW and Regulatory Policy: Problems, Text, and Cases 1 (6th ed. 2006).

27 Gundy, 139 S. Ct. at 2133.
} 
police or the courts. ${ }^{28}$ And the administrative state today, established on the basis of broad delegations of statutory authority, presents itself as a nearinevitability, as the federal government is called upon to regulate a wide range of activities. ${ }^{29}$

When Fuller delivered his Storrs Lectures in 1963, the U.S. administrative state was about to enter its most dramatic period of expansion since the New Deal. ${ }^{30}$ The administrative state's ability to harness the power of law and political organization in pursuit of substantive ends was both enticing and anxiety-provoking, particularly for those who had grown up in the aftermath of a world war against fascism and in the shadow of the Soviet Union. ${ }^{31}$ Specific critiques leveled against the administrative state in earnest during this period included charges of pervasive regulatory capture, demands that agencies respect entitlements arising from social programs, and a renewed push among business interests toward deregulation. ${ }^{32}$ More generally, critics began to express the concern that the concentration of regulatory authority in the hands of a national executive had brought about "Madison's Nightmare": extensive centralized power organized through an unintelligible cacophony of warring factional bureaucracies. ${ }^{33}$

Writing at the high-water mark of this expansion, Richard Stewart identified a transformation not only in the structure of the administrative state, but in its legitimating principles. ${ }^{34}$ Stewart observed that the "ultimate problem" of administrative law "is to control and validate the exercise of essentially legislative powers by ... agencies that do not enjoy the formal legitimation of one-person one-vote election." ${ }^{35}$ For a long time, the legitimacy of the administrative state was presumed to derive from congressional delegation: Congress defined the terms of the agency's power,

28 See Daniel Carpenter, The Evolution of National Bureaucracy in the United States, in InSTITUTIONS OF AMERICAN DEMOCRACY: THE EXECUTIVE BRANCH 41, 41 (Joel D. Aberbach \& Mark A. Peterson eds. 2005). For an example of routine contact with the administrative state, see William H. Simon, Legality, Bureaucracy, and Class in the Welfare System, 92 YALE L.J. 1198 (1983), which analyzes encounters of welfare recipients with an increasingly bureaucratized and legalized public assistance system.

29 See Stephen Breyer, MAKing Our Democracy Work: A Judge's View 107 (2010).

30 See generally BREYER ET AL., supra note 26, at 22.

31 See generally JÜRGEN HABERMAS, Legitimation CRISIS (Thomas McCarthy trans., 1973) (addressing the legitimation problems that arise with state management of the economy); DILEMMAS OF LAW IN THE WELFARE STATE (Gunther Teubner ed., 1985) (tracing the impact of the postwar welfare state on law and legal institutions).

32 BREYER ET AL., supra note 26, at 23-24.

33 Richard B. Stewart, Madison's Nightmare, 57 U. CHI. L. REV. 335, 342 (1990) (citing TheOdore J. LOWI, THE END OF LIBERALISM 200-06 (2d ed. 1978)).

34 Richard B. Stewart, The Reformation of American Administrative Law, 88 HARV. L. REV. 1667, 1670-71 (1975) [hereinafter Stewart, Reformation].

35 Id. at 1688. 
and Congress could take it back. ${ }^{36}$ Traditional administrative law, in other words, "conceives of the agency as a mere transmission belt for implementing legislative directives." ${ }^{37}$ Stewart demonstrated the failure of this transmission belt model, both in practice and in the public and theoretical imagination, as the problems of the New Deal and afterward demanded everbroader delegations from Congress. ${ }^{38}$ These problems became even more acute in the 1960s and 1970s as the administrative state's role in allocating private benefits and burdens, and the reality of capture by regulated interests, became increasingly salient. ${ }^{39}$

The breakdown of the transmission belt was also what had troubled Fuller about the administrative state, though with a different emphasis. The transmission belt offered an account of the administrative state's legitimacy, which depended on stable, generally applicable guidance from a democratically elected Congress. ${ }^{40}$ Fuller was not directly focused on democracy or legitimacy, but he was equally concerned with the role of law in setting down clear, generally applicable and prospective rules that constrain official discretion. ${ }^{41}$ But already in 1963, Fuller recognized that this conception did not describe much of what was happening in the administrative state..$^{42} \mathrm{He}$ argued that much of the administrative state's intervention into the economy dealt with "polycentric problems": complex matters of distribution that cannot be resolved through rule-governed adjudication. ${ }^{43}$ Fuller recognized that law's emphasis on generality, consistency, and stability was not appropriate to many of the tasks assigned to the administrative state, and that these tasks called instead for something like private ordering or for a kind of administrative managerialism. ${ }^{44}$ As the state becomes increasingly concerned with managing the economy, questions of institutional design would become paramount, and Fuller argued strongly against "unthinkingly" carrying over traditional models into

36 Id. at $1675 \&$ nn.20-22

37 Id.

38 E.g., id. at 1676-81.

39 Id. at $1681-88$.

40 Id. at $1675-76$.

41 FULLER, supra note 1, at 39.

42 Id. at 46 ("In recent history perhaps the most notable failure to achieve general rules has been that of certain of our regulatory agencies, particularly those charged with allocative functions.").

43 See id. at 29 (first citing Michael Polanyi, The Logic of LiBerty: Reflections AND Rejoinders (1951); then citing Michael Polanyi, Personal Knowledge: Towards A PostCRITICAl Philosophy (1958)); Lon L. Fuller, Adjudication and the Rule of Law, 54 AM. SOC'Y INT'L L. PRoc. 1, 3-5 (1960) [hereinafter Fuller, Adjudication]; Lon L. Fuller, The Forms and Limits of Adjudication, 92 HARV. L. REV. 353, 394-404 (1978).

44 FULLER, supra note 1, at 173; Fuller, Adjudication, supra note 43, at 5. 
this new era. ${ }^{45}$ What was needed, Fuller concluded, was a renewed engagement with these problems of institutional design - an engagement that required "[s]omething like the spirit of the Federalist Papers." "46

This does not mean that the administrative state is fundamentally inconsistent with Fuller's rule of law values. Administrative agencies canand often do-use the discretion granted by Congress to craft detailed systems of rules, which adopt to some extent all of Fuller's criteria. ${ }^{47}$ In principle, courts could also require agencies to constrain broad statutory discretion through rulemaking, thereby reintroducing Fuller's internal morality into the administrative state. ${ }^{48}$ But, insofar as this rulemaking took place without congressional guidance, there would need to be an alternative account of its legitimacy, which would in turn affect the form and process for agency self-control. The need for a legitimating rationale applies $a$ fortiori to the "new modes of governance" that today characterize much of the administrative state, which do not take the form of rules but of "priority setting, resource allocation, research, planning, targeting, guidance, and strategic enforcement." ${ }^{49}$

Following Fuller's call for renewed engagement, new models of administrative design and legitimation in fact began to emerge. Stewart, in particular, argued that courts responded to the failure of the transmission belt by developing an alternative "interest representation" model of administration..$^{50}$ Pursuant to this model, courts reconceived administrative policymaking as providing "a surrogate political process to ensure the fair representation of a wide range of affected interests." ${ }_{51}$ Interest representation was by no means a panacea to the administrative state's legitimacy problems - Stewart actually thought it was deeply problematic - but it nonetheless could herald a "new conception of administrative law and... political theory ... forming among the ruins of the old." ${ }_{52}$

\footnotetext{
45 FULLER, supra note 1, at 176.

46 Id. at 181.

47 See generally Elizabeth Magill, Agency Self-Regulation, 77 GEO. WASH. L. REV. 859, 859 (2009).

48 See Kenneth Culp Davis, A New Approach to Delegation, 36 U. CHI. L. REV. 713, 725-30 (1969). Some of these proposals were eventually foreclosed by the Supreme Court. See Sunstein \& Vermeule, supra note 1 , at $1936-44$.

49 Edward Rubin, It's Time to Make the Administrative Procedure Act Administrative, 89 CORNELL L. REV. 95, 97 (2003).

50 Stewart, Reformation, supra note 34, at 1723; see also Daniel B. Rodriguez \& Barry R. Weingast, The "Reformation of American Administrative Law" Revisited, 31 J.L. ECON. \& ORG. 782 (2015) (resituating this court-centric narrative within broader political developments).

51 Stewart, Reformation, supra note 34, at 1670.

52 Id. at 1811.
} 
This approach took hold in the literature. Over the following decades, scholars looked closely at emerging administrative practices and court decisions to find hints of alternative models of administrative legitimacy; they built their own models, interrogated them, and attempted to imagine alternative ways of reconstructing the administrative state, or the state itself. ${ }^{53}$ These were not simply rarefied academic theorizing: the models developed in this body of work were frequently built on the close examination of particular regulatory schemes, ${ }^{54}$ and their authors moved back and forth between policymaking roles and academia. ${ }^{55}$ By the end of the twentieth century, the administrative state - both in theory and in practice - was littered with competing models for its legitimation. ${ }^{56}$

During this period, much scholarship on the administrative state took on Fuller's "spirit of the Federalist Papers." By way of background, the Federalist Papers examine in close detail the (then-proposed) constitutional structure of U.S. government, identifying the implications of even the small details of that structure for what would now be called political science and

53 See, e.g., PhilipPe NONET \& Philip SElZnick, LAW AND SOCIETY In TRANSITION: TOWARD RESPONSIVE LAW (1978) (offering a model of "responsive law" premised on open texture, flexibility, and change); Lisa Schultz Bressman, Beyond Accountability: Arbitrariness and Legitimacy in the Administrative State, 78 N.Y.U. L. REV. 461 (2003) (arguing for a focus on non-arbitrariness as the central principle of administrative legitimacy); Steven M. Davidoff \& David Zaring, Regulation by Deal: The Government's Response to the Financial Crisis, 61 ADMIN. L. REV. 463 (2009) (arguing that the federal government's use of dealmaking suggests an alternative regulatory paradigm that should inform discussions on regulatory reform); Michael C. Dorf \& Charles F. Sabel, A Constitution of Democratic Experimentalism, 98 COLUM. L. REV. 267 (1998) (identifying an alternative form of governance based on direct participation, information pooling, goal-setting, and mutual learning); Jody Freeman, Collaborative Governance in the Administrative State, 45 UCLA L. REV. 1 (1997) (sketching a model of "collaborative governance" based on public-private responsibility sharing); Elena Kagan, Presidential Administration, 114 HARV. L. REV. 2245 (2001) (arguing that direct presidential control over regulation has displaced earlier models and is normatively and legally defensible); Orly Lobel, The Renew Deal: The Fall of Regulation and the Rise of Governance in Contemporary Legal Thought, 89 MINN. L. REV. 342 (2004) (charting the rise of "new governance" based on flexibility, public-private collaboration, and decentralization, among other characteristics); Charles F. Sabel \& William H. Simon, Minimalism and Experimentalism in the Administrative State, 100 GEO. L.J. 53 (2011) (contrasting the democratic experimentalist model of regulation with "minimalist" approaches); Mark Seidenfeld, A Civic Republican Justification for the Bureaucratic State, 105 HARV. L. REV. 1511 (1992) (arguing that a theory of civic republicanism, based on participation and deliberation, best justifies the bureaucratic state); Sidney Shapiro et al., The Enlightenment of Administrative Law: Looking Inside the Agency for Legitimacy, 47 WAKE FOREST L. REV. 463 (2012) (arguing for an alternative model of administrative legitimacy based on expertise, deliberation, and reason-giving).

${ }^{54}$ See, e.g., Freeman, supra note 53, at 55-66 (focusing on specific environmental permit negotiations).

55 Justice Elena Kagan, who is cited supra note 53 and is the author of the plurality opinion in Gundy, is only the most salient example.

56 See Richard B. Stewart, Administrative Law in the Twenty-First Century, 78 N.Y.U. L. REV. 437, 439-46, 448-53 (2003) (discussing five models or approaches of U.S. administrative law). 
political theory. ${ }^{57}$ To be sure, this was anything but a dispassionate analysis, having been prepared as an intervention into the political battle in New York over the future of the Republic..$^{5}$ But despite, or perhaps because of, the Federalist Papers' rough-and-tumble origins, its authors were engaged in a deep reflection on the design of political institutions, and the values served by the separations and connections between various government departments. ${ }^{59}$

The thinking about the administrative state in recent decades took on a similarly detail-oriented, institutionally minded approach to legitimacy. In Stewart's foundational account, for example, the new model of interest representation could be found in liberalized standing requirements, broader participation rights, and the demand to give "due regard" for the views of stakeholders. ${ }^{60} \mathrm{We}$ could use this model to then identify potential challenges (such as the problem of identifying stakeholders or gauging the impact of representation on decision-making), ${ }^{61}$ and, with the help of political theory, imagine how extending the model might resolve or exacerbate these challenges. ${ }^{62}$ Subsequent projects found new material for this kind of midlevel theorizing in negotiated rulemaking procedures, ${ }^{63}$ agency-made standard-setting processes, ${ }^{64}$ or in federal and local standards and processes for governing primary education, ${ }^{65}$ among other subjects.

But this approach also deviated from the Federalist Papers in two important respects. First, the Federalist Papers' authors were presenting what was essentially a done deal to the U.S. public. ${ }^{66}$ The administrative state, by contrast, was and remains a work in progress. Scholars and practitioners of administrative law were, to use an expression that became familiar during my short time in government, "building the airplane while

\footnotetext{
57 One could point to any essay to support this point, but a particularly vivid example is Madison's sendup of the "political maxim" that each department must be fully separate. See THE FEDERALIST NO. 47 (James Madison).

58 PAULINE MAIER, RATIFICATION 84-86 (2010).

59 WALDRON, supra note 11 , at 279.

60 Stewart, Reformation, supra note 34, at 1723-60.

${ }^{61} I d$. at $1760-90$.

62 Id. at $1790-1802$.

${ }^{63}$ Freeman, supra note 53, at 33-40.

64 Shapiro et al., supra note 53, at 491-501.

65 See generally James S. Liebman \& Charles F. Sabel, A Public Laboratory Dewey Barely Imagined: The Emerging Model of School Governance and Legal Reform, 28 N.Y.U. REV. L. \& SOC. CHANGE 183, 184 (2003).

${ }^{66}$ See MAIER, supra note 58 , at $69,86$.
} 
flying it." ${ }^{97}$ On this view, the administrative state is less something that needs to be legitimated and "sold" to a skeptical public, and more something that can be tinkered with, retheorized, and rethought in light of new internal developments or external challenges.

Second, because of this state of constant flux, much of the work on the administrative state took a decidedly critical approach to the problem of its legitimation. This is in opposition to much of Western political and legal theory which, for either transparently political reasons or for the sake of academic inquiry, have sought to explain why the existing social order is legitimate, or how it might be rendered so. ${ }^{68}$ Stewart again provides the paradigmatic example of the critical approach: he expressly describes his work as being "descriptive and critical" rather than normative, and he is neither nostalgic for the broken transmission belt model of the administrative state nor particularly optimistic about the prospects of his "interest group representation" model. ${ }^{69}$ The point of his investigation is not to identify the "right" recipe for legitimating the administrative state, but rather to recognize how the ongoing need for legitimation is reshaping the state, how small changes in doctrine or practice can signal alternative visions of our social order, and how these alternatives might respond to existing problems even as they generate new ones.

The result was a brand of intellectual engagement that treated the administrative state as a permanent problem, rather than as a sanctified part of the political order. We are stuck with the administrative state, it says, but we must neither embrace it nor reject it in favor of a romanticized past. The result is a constant churn, as new and emerging ideas take root in various corners of the state and compete to remake our institutions from the inside out - whether they be interest group pluralism, civic republicanism, presidential administration democratic experimentalism, new governance, or analytic management. To be sure, some theorists were more sanguine about their preferred governance model..$^{70}$ But this very methodology, which was based on excavating and modeling the legitimating ideas already embedded in institutional practices, carried with it the germ of critical legal studies, with its emphasis on mapping existing arrangements and reconstructing

\footnotetext{
67 This approach may echo the street-level approach to regulatory programs by the regulators themselves. See Josh Pacewicz, The Regulatory Road to Reform: Bureaucratic Activism, Agency Advocacy, and Medicaid Expansion within the Delegated Welfare State, 46 POL. \& Soc. 571, 574 (2018).

${ }^{68}$ For two succinct phrasings of the problem, both of which are emblematic of much normative jurisprudence and political theory, see JEAN-JACQUES RousSEAU, THE SOCIAL CONTRACT 49 (Betty Radice \& Robert Baldick eds., Maurice Cranston trans., Penguin Books 1968) (1762), and JOHN RAWLS, POLITICAL LIBERALISM 137 (1993).

${ }^{69}$ Stewart, Reformation, supra note 34, at 1670.

70 See, e.g., Dorf \& Sabel, supra note 53, at 283-89; Seidenfeld, supra note 53, at 1515.
} 
imagined alternatives..$^{71}$ The "models" that were produced in this fashion thus tended to be at least implicitly provisional, contestable, and subject to revision. ${ }^{72}$

The method proved portable beyond the boundaries of the United States. When studying the problems of governance beyond the state, it is useful to have tools enabling a searching and self-critical inquiry into the legitimation of power absent a direct tether to any electorate. We can therefore see hallmarks of the U.S. administrative-law method in studies of Europe's increasingly complex governance structure, ${ }^{73}$ and in studies of global regulatory bodies such as international organizations, transnational networks, and private standard-setting bodies. ${ }^{74}$ These efforts included the Global Administrative Law (GAL) project, which explicitly characterized a range of public and private global bodies as "administrative" in nature, and sought to apply to them the same diagnostic and normative tools familiar to national administrative lawyers. ${ }^{75}$ Critics sometimes dismissed much of this

71 See Roberto Mangabeira Unger, The Critical Legal Studies Movement 15-27 (1986); ROBERTO MANGABEIRA UNGER, WHAT SHOULD LEGAL ANALYSIS BECOME? 130-38 (1996) [hereinafter UNGER, LEGAL ANALYSIS].

72 See, e.g., Jean L. Cohen, Regulating Intimacy: A New Legal Paradigm 175-79 (2002). On that approach in general, see MARTTI KOSKENNIEMI, From APOLOGY TO UTOPIA: THE STRUCTURE OF INTERNATIONAL LEGAL ARGUMENT 538-48 (Cambridge Univ. Press 2005) (1989).

${ }^{73}$ For varying perspectives, see Peter L. Lindseth, Democratic Legitimacy and the Administrative Character of Supranationalism: The Example of the European Community, 99 COLUM. L. REV. 628, 642 (1999) ("Many influential European commentators, as a means of addressing the democratic deficit in Europe, increasingly draw inspiration from what they perceive to be the American model of participatory, non-hierarchical administration."); Giandomenico Majone, European Regulatory Agencies: The Dilemma of Delegation of Powers in the European Union, in RISK REGULATION IN THE EUROPEAN UNION: BETWEEN ENLARGEMENT AND INTERNATIONALIZATION 55, 56-57 (Giandomenico Majone ed., 2003) (applying Stewart's insights to EU regulatory agencies); Francesca Bignami, From Expert Administration to Accountability Network: A New Paradigm for Comparative Administrative Law, 59 AM. J. COMP. L. 859, 868-70 (2011) (tracing the history of challenges to administrative legitimacy in U.S. and European scholarship); Ming-Sung Kuo, From Administrative Law to Administrative Legitimation? Transnational Administrative Law and the Process of European Integration, 61 INT'L \& COMP. L.Q. 855,855 (2012) (drawing on U.S. and comparative administrative law to illuminate developments in the EU).

74 See generally Eyal BenVenisti, The LAW of Global Governance (2014) (arguing that decision-making in global governance bodies should be subject to the same types of constraints that apply in domestic administrative law); Joshua Cohen \& Charles F. Sabel, Global Democracy?, 37 N.Y.U. J. INT'L L. \& POL. 763 (2005) (theorizing global administrative networks in a manner similar to Sabel's earlier work on democratic experimentalism in the U.S.); Daniel C. Esty, Good Governance at the Supranational Scale: Globalizing Administrative Law, 115 YALE L.J. 1490 (2006) (arguing that the tools of administrative law should be applied to regulate international policymaking).

75 See generally Lorenzo Casini, Global Administrative Law, in INTERNATIONAL LEGAL THEORY: Foundations AND FRONTIERS (Jeffrey L. Dunoff \& Mark A. Pollack eds., forthcoming), https://papers.ssrn.com/a=3328120 [https://perma.cc/4454-F5FL] (surveying the history of global administrative law methodology); Benedict Kingsbury, Nico Krisch \& Richard B. Stewart, The 
literature as a naïve and somewhat neoliberal normative project. ${ }^{76}$ But, in the critical spirit of this line of administrative-law scholarship, a great deal of work in the GAL vein was dedicated to capturing the normative and practical dynamics of institutional churn, reconstructing alternative possible futures embedded in existing arrangements, and subjecting them to critique. ${ }^{77}$

Emergence of Global Administrative Law, 68 L. \& CONTEMP. PROBS. 15 (2005) (identifying an emerging "global administrative space" that is becoming subject to administrative-law-like requirements such as reason-giving, transparency, and review); Nico Krisch \& Benedict Kingsbury, Introduction: Global Governance and Global Administrative Law in the International Legal Order, 17 EUR. J. INT'L L. 1 (2006) (situating these emerging global administrative phenomena in relation to public international law); Richard B. Stewart, Remedying Disregard in Global Regulatory Governance: Accountability, Participation, and Responsiveness, 108 AM J. INT'L L. 211 (2014) (conceptualizing accountability in global administration).

${ }^{76}$ See, e.g., David Kennedy, The Mystery of Global Governance, in RULING THE WORLD?: Constitutionalism, International LaW, and Global GovernanCe 37, 64 (Jeffrey L. Dunoff \& Joel P. Trachtman eds., 2009). There were also some concerns about GAL's failure to engage with democracy, which were only later addressed by its founders. See Benedict Kingsbury et al., Global Administrative Law and Deliberative Democracy, in THE OXFORD HANDBOOK OF THE THEORY OF InTERNATIONAL LAW 526, 526 (Anne Orford, Florian Hoffman \& Martin Clark eds., 2016); Peter L. Lindseth, Equilibrium, Demoi-cracy, and Delegation in the Crisis of European Integration, 15 GER. L.J. 529, 555 (2014); Susan Marks, Naming Global Administrative Law, 37 N.Y.U. J. INT'L L. \& PoL. 995, 999-1001 (2005); Kalypso Nicolaidis \& Gregory Shaffer, Transnational Mutual Recognition Regimes: Governance Without Global Government, 68 L. \& CONTEMP. PROBS. 263, 314 (2005).

77 See, e.g., Eyal Benvenisti, Upholding Democracy Amid the Challenges of New Technology: What Role for the Law of Global Governance?, 29 EUR. J. INT'L L. 9 (2018) (arguing that new technologies now pose a fundamental challenge to administrative-law principles that constrain governance institutions); B.S. Chimni, Co-option and Resistance: Two Faces of Global Administrative Law, 37 N.Y.U. J. INT'L L. \& POL. 799 (2005) (exploring the limited ability of global administrative law to constrain imperial power); J. Benton Heath, Managing the "Republic of NGOs": Accountability and Legitimation Problems Facing the UN Cluster System, 47 VAND. J. TRANSNAT'L L. 239 (2014) (critiquing the emerging "horizontal accountability" structure in the U.N. humanitarian system); Paul Mertenskötter \& Richard B. Stewart, Remote Control: Treaty Requirements for Regulatory Procedures, 104 CORNELL L. REV. 165 (2018) (arguing that newer trade treaties are being used to reshape the domestic administrative state to favor powerful transnational actors); Bronwen Morgan, Turning Off the Tap: Urban Water Service Delivery and the Social Construction of Global Administrative Law, 17 EUR. J. INT'L L. 215 (2006) (exploring the dual roles of political protest and technical expertise in constructing global administrative spaces); Gus Van Harten \& Martin Loughlin, Investment Treaty Arbitration as a Species of Global Administrative Law, 17 EUR. J. INT'L L. 121 (2006) (using the label "global administrative law" to expose certain aspects of the investment treaty arbitration system). Of course, U.S. administrative law was not the only tradition that had something to say about global institutions. For examples drawing on a continental tradition, see THE EXERCISE OF PUBLIC AUTHORITY BY INTERNATIONAL INSTITUTIONS: ADVANCING INTERNATIONAL INSTITUTIONAL LAW (Armin von Bogdandy et al. eds., 2010). For instances from outside the Global North, see, for example, Mariana Mota Prado, Presidential Dominance from a Comparative Perspective: The Relationship Between the Executive Branch and Regulatory Agencies in Brazil, in COMPARATIVE ADMINISTRATIVE LAW 225, 225 (Susan Rose-Ackerman \& Peter L. Lindseth eds., 2010); Chimni, supra, at 806-11. But, owing to the privileged position of U.S. experts and scholars and the influence of the United States on the postwar international order, it was particularly influential. On the Western tilt in GAL, see Carol Harlow, Global Administrative Law: The Quest for Principles and Values, 17 EUR. J. INT'L L. 187, 187 (2006) (warning that administrative law is "primarily a Western construct, protective of Western interests"). 
All of this intellectual development and expansion was made possible by the breakdown of Stewart's transmission belt. If it were possible to control and legitimate the kind of administrative state that we want through clear delegations laid down in advance by Congress and reviewed by courts, then there would be no need to launch a decades-spanning intellectual project to continually reimagine the state's legitimating principles. There would have been no special need to think deeply about which doctrinal and practical developments suggest alternative futures for the design of the administrative apparatus and its relationship to the governed. ${ }^{78}$ And there would have been few lessons for global and private administrative bodies, or for any discipline that studies the legitimation problems facing governance under conditions of complexity, electoral breakdown, or globalization.

This is not to say that the intellectual study of the administrative state has been some unqualified good. Certainly, no one has "solved" the legitimation problems of the modern administrative state, and even seemingly good ideas can be pathological in practice or fall prey to "the tendency of any large bureaucracy to water down transformational concepts until they cease to have much real meaning." ${ }^{\prime 9}$ Critics from the left have long argued that much of this mainstream scholarship only serves to entrench bureaucracy as the dominant form of social organization. ${ }^{80}$ If theorists are too preoccupied by the legitimacy of the administrative state, this argument goes, then they may too readily accept the false necessity of bureaucracy and too easily presume the legitimacy of the rest of the constitutional structure.

Other critiques of administrative legitimacy embrace the modern necessity for the bureaucratic administrative state but come close to suggesting that we jettison any special desire for its democratic legitimation. Consider, for instance, Adrian Vermeule's invocation of Carl Schmitt as a basis for theorizing the administrative state, ${ }^{81}$ or Edward Rubin's deliberately provocative suggestion that we bracket any notion of democracy or legitimacy in favor of sterile concepts drawn from management science and engineering. ${ }^{82}$ More recently, Nicholas Bagley forcefully argued that this

\footnotetext{
${ }^{78}$ No special need, that is, beyond the general problem that in political life nearly every exercise of government power suffers from some legitimacy deficit. See infra Part III.

79 Rosa Brooks, How Everything Became War AND the Military BeCAME Everything 150 (2016).

80 See Gerald E. Frug, The Ideology of Bureaucracy in American Law, 97 HARV. L. REV. 1276 (1984). For a brief response that probably would not have mollified Frug, see PHILIP SELZNICK, THE Moral Commonwealth: SOCIAL TheORY AND THE Promise OF COMMUNiTy 258-60 (1992).

${ }^{81}$ Adrian Vermeule, Our Schmittian Administrative Law, 122 HARV. L. ReV. 1095 (2009); see also Eric A. Posner \& Adrian Vermeule, Crisis Governance in the Administrative State: 9/11 and the Financial Meltdown of 2008, 76 U. CHI. L. REV. 1613 (2009).

82 Edward L. Rubin, Beyond CAmelot: Rethinking Politics AND LAW For the Modern STATE (2005).
} 
preoccupation with legitimacy has caused progressives to effectively cede control over the administrative state to a deregulatory Republican agenda. ${ }^{83}$ While Bagley does not reject the need for legitimacy in the administrative state, he contends that talk of any "democratic deficit" of agencies vis-à-vis the other branches of government is overblown, such that the continuing quest for legitimacy among administrative lawyers is a "sucker's game." ${ }^{4}$

Taken together, these critiques highlight a tension at the center of the mainstream intellectual project. Mainstream administrative law and theory, as I have described it, attempts to take seriously both the necessity of the modern administrative apparatus and its need for democratic legitimation. This tension produces two opposite risks. On the one hand, the concession to practical necessity could devolve into apologia for the bureaucratic administrative state, squeezing out any vision for alternative forms of social organization. ${ }^{85}$ On the other, the endless quest for legitimation risks hamstringing effective governance by effectively blessing any procedural control, no matter how onerous. ${ }^{86}$

This tension, though, is what made the U.S. administrative-law project of the past forty years so generative of new ideas. Theories of the administrative state that were able to navigate this tension-that could maintain a commitment to thinking beyond both the received institutional structures and received notions of what it means to be "democratic"- - offered genuinely novel contributions to the question of what it means to legitimately govern under conditions of complexity. ${ }^{87}$ Such theories were eminently practical without abandoning imagination. They were committed to both the administrative apparatus and democracy, without purporting to offer a romanticized understanding of either. And the U.S. administrative state was, on this view, a laboratory for experiments in designing democracy under conditions of extreme complexity, technocracy, and globalization. This was, perhaps, something like the "spirit of the Federalist Papers" that Fuller imagined.

\section{NONDELEGATION'S REVIVAL: DISPELLING FULLER'S SPIRIT?}

The apparent revival of the nondelegation doctrine may signal the end of this experimentalist spirit, at least for the time being. As noted above, there is a large contingent of theorists, lawyers, and politicians for whom everything just said about the "spirit of the Federalist Papers" verges on

83 Nicholas Bagley, The Procedure Fetish, 118 Mich. L. REV. 345, 348-50 (2019).

${ }^{84}$ Id. at $377-78$.

85 This is the outcome that worried Frug, supra note 80, at 1384-88.

86 Bagley, supra note 83, at 378 .

87 See supra note 53 and sources cited therein. 
dangerous nonsense. On this view, roughly stated, the U.S. Constitution itself is the experiment in democracy, and it places broad but significant limits on the functions that each branch may perform. For some, these limits render much of modern administrative government unconstitutional, at least in its current form. ${ }^{88}$ The administrative state may be an experiment in something - it may even be someone's idea of democracy - but it is not constitutional democracy.

Much of the doctrinal force of this criticism is geared toward restarting the transmission belt, and that means reviving the nondelegation doctrine..$^{89}$ Most everyone agrees that Congress cannot constitutionally delegate its legislative power to any other department or body, but the parameters of this limitation are deeply disputed..$^{90}$ In 1935 , the Supreme Court took a relatively expansive view of the limitation in two cases, declaring unconstitutional two parts of a New Deal-era statute, on the ground that Congress had effectively abdicated its legislative function. ${ }^{91}$ This came to be known as the "nondelegation doctrine." But, since that year, the Court has never again applied the doctrine to invalidate a statute, allowing instead for even broad policymaking delegations to stand so long as they provide the agency with an "intelligible principle" to guide their decisions. ${ }^{92}$ This broad standard effectively acknowledged that the transmission belt was not the way to police the administrative state and set the stage for broad delegations to regulate "in the public interest" or to impose standards "requisite to protect the public health." 93

\footnotetext{
88 See Gary Lawson, The Rise and Rise of the Administrative State, 107 HARV. L. REV. 1231, 1231 (1994).

89 See Theodore J. Lowi, The End of Liberalism (2d ed. 1978); Gary Lawson, Discretion as Delegation: The "Proper" Understanding of the Nondelegation Doctrine, 73 GEO. WASH. L. REV. 235 (2005); Cass R. Sunstein \& Adrian Vermeule, Libertarian Administrative Law, 82 U. CHI. L. ReV. 393, 414-23 (2015). In painting these developments with a broad brush, I am necessarily passing over significant differences among critics. Theodore Lowi, for example, was a longtime critic of broad delegations and cannot readily be assimilated to any of the political camps that we now see lining up around this issue. See generally Theodore J. Lowi, Two Roads to Serfdom: Liberalism, Conservatism and Administrative Power, 36 AM. U. L. REV. 295 (1987) [hereinafter Lowi, Serfdom].

90 See Eric A. Posner \& Adrian Vermeule, Interring the Nondelegation Doctrine, 69 U. CHI. L. REV. 1721, 1726 (2002) (citing Mistretta v. United States, 488 U.S. 361, 424-25 (1989) (Scalia, J., dissenting)).

91 See A.L.A. Schechter Poultry Corp. v. United States, 295 U.S. 495, 530-42 (1935) (concerning poultry industry regulations that had been adopted pursuant to the National Industrial Recovery Act of 1933 (NIRA)); Panama Refining Co. v. Ryan, 293 U.S. 388, 414-33 (1935) (concerning petroleum trade restrictions adopted pursuant to the NIRA).

92 See, e.g., Whitman v. Am. Trucking Ass'ns, Inc., 531 U.S. 457, 472 (2001); Touby v. United States, 500 U.S. 160, 165 (1991); see also Gundy v. United States, 139 S. Ct. 2116, 2123 (2019) (plurality opinion) (noting that this standard has been applied "time and again"); id. at 2138-41 (Gorsuch, J., dissenting) (offering a revisionist history of the "intelligible principle" doctrine).

93 Gundy, 139 S. Ct. at 2129 (plurality opinion); see infra notes 109-110 and accompanying text.
} 
The case Gundy v. United States, decided in June 2019, offered an opportunity to take the new Court's temperature on this expansion. Herman Gundy challenged a provision of the Sex Offender Registration and Notification Act (SORNA), which delegates to the Attorney General the authority to "specify the applicability" of the Act's registration requirements to persons who were convicted prior to its enactment. ${ }^{94}$ Knowingly failing to register was a crime that carried a maximum sentence of ten years in prison..$^{95}$ Gundy - a pre-enactment sex offender who was convicted of failing to register in accordance with the Attorney General's rules - argued that the Act was an unconstitutional delegation of legislative power because it effectively gave the Attorney General carte blanche to legislate crimes. ${ }^{96}$ Justice Kagan, announcing the opinion of the Court and writing for a fourmember plurality, categorically rejected the challenge, finding that the Act's structure, purpose, and history provided an "intelligible principle" to guide the exercise of delegated authority, placing the statute well within constitutional bounds. ${ }^{97}$

More interesting going forward, however, are the concurring and dissenting opinions, in which four of the Court's conservative Justices signaled a willingness to revive and expand the nondelegation doctrine. Concurring in the Court's judgment, Justice Alito stated that he would "support" an effort to "reconsider the approach we have taken for the past 84 years" to the nondelegation doctrine, if in a future case a majority of the Court would be willing to do so. ${ }^{98}$ Justice Gorsuch dissented, joined by Chief Justice Roberts and Justice Thomas, to argue that he "would not wait" for such an opportunity. ${ }^{99}$ The nondelegation doctrine, Gorsuch argued, is essential to securing the Constitution's promise that "only the people's elected representatives may adopt new federal laws restricting liberty."100

The dissenting opinion supports its proposed revival of the nondelegation doctrine with a vision of classical liberal constitutionalism. ${ }^{101}$ By insisting that Congress agree on the terms of its delegation to administrative agencies through ordinary Article I procedures, the nondelegation doctrine secures "the people's liberty" against an "excess of

\footnotetext{
9434 U.S.C. § 20913(d) (2012); Gundy, 139 S. Ct. at 2122.

9518 U.S.C. $\S 2250$ (a) (2012).

96 Gundy, 139 S. Ct. at 2122.

97 Id. at 2129-30 (finding that the law required the Attorney General to order the registration of preSORNA offenders "as soon as feasible" and finding this delegation to be constitutionally sound).

98 Id. at 2131 (Alito, J., concurring in the judgment).

99 Id. (Gorsuch, J., dissenting).

$100 \mathrm{Id}$.

101 See id. at 2133-35.
} 
law-making" by "mak[ing] lawmaking difficult."102 The nondelegation doctrine also fosters deliberation among lawmakers, promotes the rule of law by ensuring the stability and generality of laws, enhances accountability of elected officials by forcing them to own their decisions, and generally protects minorities by leveraging the separation of powers to ensure that "ambition" is made to "counteract ambition." 103 Congress can, consistent with these principles, announce a broad regulatory policy and authorize the administration to "fill up the details," make the application of a rule dependent on executive factfinding, or delegate to non-legislative authorities. ${ }^{104}$ But, if Congress goes further, then the Court "must call foul when the constitutional lines are crossed." 105

The dissent also sends some rather clear signals that it agrees with Justice Kagan's assertion that "if SORNA's delegation is unconstitutional, then most of Government is unconstitutional...."106 For example, the dissent suggests that the "feasibility standard" that the plurality found to supply the statute's "intelligible principle" would not pass constitutional muster. ${ }^{107}$ The dissenting opinion also takes a slight detour to quote Justice Douglas's view that "Congress defaulted when it left it up to an agency to do what the 'public interest' indicated should be done." 108 These types of delegations - requiring agencies to regulate in the public interest or to take "feasible" measures - are exactly the sort of provisions that appear in numerous statutes previously upheld by the Court, and which form the basis

102 Id. at 2134 (quoting THE FEDERALIST No. 62 (James Madison)).

103 Id. (quoting THE FEDERALIST No. 51 (James Madison)). Notably, Madison's observation that ambition must be made to counteract ambition is also an animating motive behind much mainstream scholarship on the structure and legitimation of the administrative state. See, e.g., SELZNICK, supra note 80, at 334-36 (suggesting that these Madisonian principles have "broader relevance" to public and private affairs).

104 Gundy, 139 S. Ct. at 2136 (Gorsuch, J., dissenting) (citation omitted).

$105 I d$. at 2135 .

106 Id. at 2120 (plurality opinion).

107 Id. at $2145-46$ (Gorsuch, J., dissenting). The dissent also disagreed with the plurality that the statute contained a feasibility standard at all, but more interesting is its discussion of the standard's constitutionality. See id. at 2145 ("A statute directing an agency to regulate private conduct to the extent 'feasible' can have many possible meanings: It might refer to 'technological' feasibility, 'economic' feasibility, 'administrative' feasibility, or even 'political' feasibility. Such an 'evasive standard' could threaten the separation of powers if it effectively allowed the agency to make the 'important policy choices' that belong to Congress while frustrating 'meaningful judicial review.' And that seems exactly the case here, where the Attorney General is left free to make all the important policy decisions and it is difficult to see what standard a court might later use to judge whether he exceeded the bounds of the authority given to him.").

108 Id. at 2140 n.63 (quoting William O. Douglas, Go EASt, Young Man: THE EARLY Years 217 (1974)). The quote continues: “Public interest' is too vague a standard to be left to free-wheeling administrators. They should be more closely confined to specific ends or goals." Id. 
of much modern regulatory activity. ${ }^{109}$ The dissenting opinion also notably draws on scholarship arguing explicitly that key components of the modern state - including provisions of the Securities and Exchange Act of 1934, the Communications Act of 1934, and the Clean Air Act-are "easy cases" for unconstitutional delegations. ${ }^{110}$ Given these signals throughout the opinion, many will not be comforted by the dissent's insistence that nothing it says would "spell doom for what some call the 'administrative state." 111

Given the split nature of this decision, it remains unclear whether doom is on its way. Since Gundy, there has been no shortage of predictions about how Justice Kavanaugh would rule if the nondelegation issue were raised in a new case. ${ }^{12}$ When sitting on the D.C. Circuit Court of Appeals, then-Judge Kavanaugh certainly was skeptical of creative congressional delegations and willing to deploy his own reading of the text and structure of the Constitution to strike down institutional experiments by Congress. ${ }^{113}$ And more recently, Justice Kavanaugh has signaled his agreement with the dissenters' arguments in Gundy. ${ }^{114}$ Nevertheless, as Adrian Vermeule recently pointed out, when it comes to dismantling the nondelegation doctrine, there is a big difference between talking the talk in dissent and walking the walk in a controlling opinion, and there is some history of conservative-leaning Justices doing the former but not the latter. ${ }^{115}$ There may thus be reason to

109 See, e.g., Nat'1 Broad. Co. v. United States, 319 U.S. 190, 214 (1943) (upholding Section 303 of the Communications Act of 1934, 47 U.S.C. $\S 303$ (2012), which enables the Federal Communications Commission to make regulations on certain subjects "from time to time, as public convenience, interest, or necessity requires"). The Gundy plurality noted other statutes that use "feasibility" as a principle to guide regulatory policymaking. Gundy, $139 \mathrm{~S}$. Ct. at 2130 (plurality opinion) (citing 12 U.S.C. § 1701z2(a) (2012) and 47 U.S.C. $§ 903(d)(1)(2012))$.

110 See, e.g., Gary Lawson, Delegation and Original Meaning, 88 VA. L. REV. 327, 379-81 (2002) (cited in Gundy, 139 S. Ct. at 2135 n.29 (Gorsuch, J., dissenting)). Lawson notably states that he is "agnostic" on the question of whether the Court itself should apply the nondelegation doctrine. Lawson, supra, at 335. But the Gundy dissent is not.

111 Gundy, 139 S. Ct. at 2145.

112 For an early appraisal of such efforts, see Mark Tushnet, Talking About Judge Kavanaugh as a Justice, BALKINIZATION (July 10, 2018), https://balkin.blogspot.com/2018/07/talking-about-judgekavanaugh-as-justice.html [https://perma.cc/ZN83-K2AX].

113 See PHH Corp. v. Consumer Fin. Prot. Bureau, 839 F.3d 1, 36 (D.C. Cir. 2016), petition for review granted in part and denied in part and remanded en banc, 881 F.3d 75 (D.C. Cir. 2018).

114 Paul v. United States, 140 S. Ct. 342, 342 (2019) (statement of Kavanaugh, J., respecting the denial of certiorari) ("Justice Gorsuch's scholarly analysis of the Constitution's nondelegation doctrine in his Gundy dissent may warrant further consideration in future cases.”).

115 Adrian Vermeule, Never Jam Today, NoticE \& COMMENT (June 20, 2019), https://yalejreg.com/nc/never-jam-today-by-adrian-vermeule [https://perma.cc/X3D9-8JS9] ("Ever since I started law school in 1990, almost thirty years ago, I've been hearing that the Court's libertarian-legalist conservatives would definitely invalidate some statute or other on nondelegation grounds, any day now, without question .... And yet somehow, when push came to shove, when it was a question of actually 
suspect that a modified version of the status quo could continue, with nondelegation continuing to serve only a background role as a canon of avoidance and statutory construction. ${ }^{116}$

Nevertheless, the retrograde transmission belt model of administration implied in the Gundy dissent does signal a profound shift in the intellectual project of the U.S. administrative state. The dissent's particular view of the nondelegation doctrine draws its normative force from a relatively inactive administration: Congress either reaches agreement through robust deliberation on the precise parameters of its delegation or it does not delegate at all, and either outcome is assumed to vindicate individual liberty. ${ }^{117} \mathrm{In}$ reaction to this position, defenders of the administrative state are forced to justify not only particular regulatory programs, but the very act of regulation itself as an enterprise that can equally be supportive of some constellation of constitutional values. This reactive position can be seen in recent work that warns of "anti-administrativist" tendencies on the Court and attempts to offer a comprehensive constitutional justification for the administrative state. ${ }^{118}$

This realignment heralds a return to old-style legitimacy politics, and a turn away from the Fullerian spirit discussed above. When the very existence of the bureaucracy is at stake, there is little room for cautious optimists to treat the regulatory state as a permanent problem, or even to be entirely candid as to their own skepticism about its legitimacy. Instead, the administrative state is presented and defended as already legitimate. On the other side, anti-administrativist forces call into question the entire regulatory enterprise by reference to the imagined legitimacy of a romanticized past. Neither of these positions takes seriously the legitimacy of institutions as

assembling five votes to declare a federal statute unconstitutional on grounds not invoked for decades, grounds that would threaten to destabilize much of the modern administrative state - when it came time to $a c t$, as opposed to venting one's constitutional frustrations in concurrence and dissents - well, it never did quite happen. Justice Scalia's Mistretta dissent became his brusque opinion in Whitman v. American Trucking, sweeping aside a serious nondelegation challenge to the Clean Air Act. Jam yesterday (yesterday being 1935), and jam tomorrow, but never jam today.").

116 Cf. Cass R. Sunstein, Nondelegation Canons, 67 U. CHI. L. REv. 315, 315-16 (2000) (arguing that the doctrine of nondelegation has been "relocated" so that "nondelegation canons" now are relied upon "to forbid administrative agencies from making decisions on their own"); Lisa Schultz Bressman, Disciplining Delegation After Whitman v. American Trucking Ass'ns, 87 CoRNell L. REV. 452, 455 (2002) (arguing that the Supreme Court "has shifted the focus from constitutional law to administrative law as a basis for requiring administrative standards" that guide administrative policymaking). Continental jurisdictions, where a version of the nondelegation doctrine continues to play a vital role in constitutional law and politics, may offer visions of alternative equilibria. See Peter L. Lindseth, The Paradox of Parliamentary Supremacy: Delegation, Democracy, and Dictatorship in Germany and France, 1920s-1950s, 113 YALE L.J. 1341, 1354-71 (2004) (describing the German version).

117 Gundy v. United States, 139 S. Ct. 2116, 2145 (2019) (Gorsuch, J., dissenting).

118 See, e.g., Metzger, supra note 21. 
they actually exist - always in doubt, failing to live up to their boldest promises, and suggestive of alternative futures.

\section{LEGITIMACY'S END}

In short, the immediate consequence of the rising anti-administrativism on the Court may be a fundamental shift in the terms of our engagement with what it means to be legitimately and democratically governed. For four decades, mainstream administrative law offered a singular laboratory for problematizing and rethinking what it means to be democratically governed under contemporary conditions. This was an oddly critical counterpoint to much normative legal and political theory, which during the same period remained concerned with defending the legitimacy of some idealized conception of liberal democracy. But this experimental spirit was only made possible by the recognized breakdown of the administrative transmission belt. The Court's latest effort to jumpstart that transmission belt thus signals a return to dueling visions of the ideal constitutional structure, which threatens to crowd out any remaining attempts at experimentation. It therefore serves to close by reflecting on what may come next.

The same week that Gundy was handed down, intellectuals recognized the ninetieth birthday of Jürgen Habermas. For much of his life, Habermas has worked firmly in the Western philosophical tradition, taking as his central problem the "legitimacy" of power relations. ${ }^{119}$ Habermas's "discourse" theory of democracy-which takes as its regulative ideal the concept of rational, unforced deliberation - appears at first blush to be wellsuited to address the tensions between technocratic rationality and political action in the modern administrative state. ${ }^{120}$ And, indeed, Habermas's theory has provoked a great deal of thinking about administration and democracy, both in the United States and beyond. ${ }^{121}$

\footnotetext{
119 E.g., JÜRGEN HABERMAS, Legitimation Problems in the Modern State, in COMMUNICATION AND THE EVOLUTION OF SOCIETY 178 (Thomas McCarthy trans., Beacon Press 1979) (1976).

${ }^{120}$ Habermas's own approach to the administrative state has much in common with Fuller's spirit, though he arguably demands a greater level of engagement by parliament. See JÜRGEN HABERMAS, BETWEEN FACTS AND NORMS: CONTRIBUTIONS TO A DISCOURSE THEORY OF LAW AND DEMOCRACY 440-41 (William Rehg trans., MIT Press 1996) (1992). For a critique, see RUBIN, supra note 82, at 15960.

121 See B. S. Chimni, Reforming the International Refugee Regime: A Dialogic Model, $14 \mathrm{~J}$. Refugee Stud. 151, 164-65 (2001); Joshua Cohen \& Charles Sabel, Directly-Deliberative Polyarchy, 3 EUR. L.J. 313, 337-42 (1997); Esty, supra note 74, at 1520-21; A. Michael Froomkin, Habermas@discourse.net: Toward a Critical Theory of Cyberspace, 116 HARV. L. REV. 749, 751-52 (2003); Timur Kuran \& Cass R. Sunstein, Availability Cascades and Risk Regulation, 51 StAN. L. ReV. 683, 737 (1999); Jerry L. Mashaw, Small Things Like Reasons Are Put in a Jar: Reason and Legitimacy in the Administrative State, 70 FordHAM L. REV. 17, 29-30 (2001); Eric W. Orts, Reflexive Environmental Law, 89 Nw. U. L. REV. 1227, 1255, 1258 n.130 (1995).
} 
Longtime critic Raymond Geuss took the opportunity of this day to call into question the legacy of Habermas and his fellow travelers. For Geuss, the Western philosophical tradition need not be preoccupied with legitimating the existing institutions of liberal democracy. He writes:

[I]t is a Kantian prejudice that "legitimation" is the basic problem of philosophy or even the basic problem of philosophy in the modern era. It is even less plausible to think that it is the basic social problem of the modern world ....

The foolish claim that "we live in the best of all possible worlds" is not the best defense of the status quo. It is much more effective to hide one's affirmation of the given social and economic structures, while trumpeting the opportunities one's philosophy provides for criticizing a wide variety of individual flaws, defects and inadequacies. An ideology of "discursive criticism" also has much better chances of establishing itself because of certain psychological advantages it gives to those who adopt it. It is well suited to absorb, deflect and channel destructive energies that might otherwise get out of hand, by, thanks be to Kant, imposing discipline on existing discontent and dissipating it in small packets of reformist criticism of individual imperfections and blemishes of the social system. ${ }^{122}$

At the risk of aggrandizing this corner of U.S. law, it may serve to think of recent developments in the administrative state as being consistent with this broader pull away from the politics of legitimacy. A clash between socalled administrativist and anti-administrativist forces would in some sense be the reduction to absurdity of Western thought's concern with legitimating state institutions. The diffusion of coercive public power throughout a vast, impersonal bureaucracy that is largely unintelligible to the average citizen cannot be said to be unproblematically "legitimate" in any meaningful sense of that term. At the same time, there is likely no danger of the antiadministrativist position casting the United States back to the nineteenth century, simply because the practical constraints are just too strong. ${ }^{123}$ The most likely outcome of this clash, then, is a case-by-case resolution of challenges to the administrative state, with each side retroactively claiming legitimacy from its preferred source.

From the perspective of critical theory, this development could be viewed as an opportunity. As the Fullerian period of U.S. administrative law

\footnotetext{
122 Raymond Geuss, A Republic of Discussion: Habermas at Ninety, PoINT (June 18, 2019), https://thepointmag.com/2019/politics/republic-of-discussion-habermas-at-ninety [https://perma.cc/F2LP-46SG].

123 See Jeannie Suk Gersen, The Supreme Court Is One Vote Away from Changing How the U.S. Is Governed, NEW YORKER (July 3, 2019), https://www.newyorker.com/news/our-columnists/the-supremecourt-is-one-vote-away-from-changing-how-the-us-is-governed [https://perma.cc/4SC4-5TDL].
} 
comes to a close, ${ }^{124}$ there is no longer any need for quasi-critical theory to act as the handmaiden of existing institutions and power relations. Critical work on the administrative state will no longer have to reduce itself to what Geuss evocatively calls "small packets of reformist criticism" in order to be heard, because no one will be listening. There will be no need to compromise the impulse to radical critique by, for example, accepting the false necessity of bureaucracy, or by treating the elected legislature as a yardstick for legitimacy. Meanwhile, the clash between opposing forces over the existing administrative state will continue to litter corners of U.S. administrative law with the vestiges of past and discarded solutions, ripe for recombination in new constructive-critical projects. ${ }^{125}$

But that critical project would not be a mainstream one. The turn away from the Fullerian spirit in administrative law would spell the end of one interesting corner of U.S. legal theory and practice, where it was acceptable to openly question what it means to be democratically governed under conditions of deepening complexity. The critical method and the drive for legitimation were perhaps always uneasy partners in this endeavor, and their coexistence surely kept out some of the more unruly responses to the dominant political order. But, in exchange, this partnership created a space where experiments in legitimacy could be carried out with the backing of the state and interrogated openly and critically. If that searching intellectual project is lost - and the constellation of decisions in Gundy suggests that it is - then that is something to be mourned.

124 Here, I've used Fullerian in the sense just described - a spirit of open and constructive inquiry into the problems of institutional design — and not in the sense used recently by Sunstein and Vermeule to describe doctrines that enforce Fuller's principles of legality in administrative law. Sunstein \& Vermeule, supra note 1, at 1965-67. As noted supra, in my view these authors have understated the extent to which Fuller understood and appreciated the problems posed by the administrative state, and they do not directly engage with Fuller's comments on institutional design.

125 Cf. UNGER, LEGAL ANALYSIS, supra note 71, at 65-67 ("Law produced through . . . irremediable conflict will be messy, and all the more messy in a democracy valuing and institutionalizing pluralism.”). 